RIBEIRO, WS; CARNEIRO, CS; FRANÇA, CFM; PINTO, CMF; LIMA, PCC; FINGER, FL; COSTA, FB. 2019. Paclobutrazol application in potted ornamental pepper. Horticultura Brasileira 37: 464-468. DOI - http://dx.doi.org/10.1590/S0102-053620190416

\title{
Paclobutrazol application in potted ornamental pepper
}

\author{
Wellington S Ribeiro ${ }^{1} \mathbb{D}$; Clebson dos S Carneiro ${ }^{2} \mathbb{D}$; Christiane de Fátima M França ${ }^{4} \mathbb{D}$; Cleide Maria F \\ Pinto ${ }^{3 \mathbb{D}}$; Paula Cristina C Lima ${ }^{2} \mathbb{D}$; Fernando L Finger ${ }^{2} \mathbb{D}$; Franciscleudo B da Costa ${ }^{1} \mathbb{D}$
}

${ }^{1}$ Universidade Federal de Campina Grande UFCG), Pombal-PB, Brasil: wellingtisouto@yahoo.com.br; ${ }^{2}$ Universidade Federal de Viçosa (UFV), Viçosa-MG, Brasil: ffinger@ufv.br; paulinhahlima@yahoo.com.br; clebson.carneiro@ufv.br; ${ }^{3}$ Empresa de Pesquisa Agropecuária de Minas Gerais (EPAMIG), Viçosa-MG, Brasil: cleidemariaferreirapinto@yahoo.com.br; ${ }^{4}$ Universidade Federal do Oeste da Bahia (UFOB), Barra-BA, Brasil; christiane.franca@ufob.edu.br

\begin{abstract}
Within the genetic variability of the Capsicum genus there are plants with ornamental potential, but awry height required by the market. Paclobutrazol (PBZ), gibberellin retardant and growth inhibitor, is normally used as alternative to reduce plant height. The objective was to evaluate the $\operatorname{PBZ}\left(0,25,50\right.$ and $\left.75 \mathrm{mg} \mathrm{L}^{-1}\right)$ effect on plant height of eight pepper genotypes. Seven accessions [BGH 1032, BGH 1039, BGH 7073 (C. annuum), BGH 4285, BGH 4199, BGH 4355 and BGH 6371 (C. chinense)] of the germplasm bank from Universidade Federal de Viçosa and one access [MG 302 (C. annuum)] from the germplasm bank of the Empresa de Pesquisa Agropecuária de Minas Gerais were evaluated. The PBZ application was ineffective in altering plant architecture of BGH 6371. PBZ at $25 \mathrm{mg} \mathrm{L}^{-1}$ resulted in plants with better ornamental characteristics of the accesses BGH 1032 and BGH 1039. Considering the cost-benefit, the indicated dose for BGH 4285, BGH 7073 and MG 302 access is $25 \mathrm{mg} \mathrm{L}^{-1} \mathrm{PBZ}$. The PBZ application in BGH 4199 and BGH 4355 accesses, despite reducing plant height, did not improve the ornamental characteristics, resulting in plants without canopy pattern.
\end{abstract}

Keywords: Capsicum annuum, Capsicum chinense, market, ornamental plants.

\section{RESUMO}

Aplicação de paclobutrazol em pimenteiras ornamentais cultivadas em vaso

Dentro da variabilidade genética no gênero Capsicum há plantas com grande potencial ornamental, mas com altura desconforme da exigida pelo mercado. A aplicação de paclobutrazol (PBZ), retardante de crescimento e inibidor das giberelinas, é uma alternativa para reduzir a altura das plantas. $\mathrm{O}$ objetivo foi avaliar o efeito de diferentes concentrações de $\operatorname{PBZ}\left(0,25,50\right.$ e $\left.75 \mathrm{mg} \mathrm{L}^{-1}\right)$ sobre oito genótipos de pimenteiras. Sete acessos [BGH 1032, BGH 1039, BGH 7073 (C. annuum), BGH 4285, BGH 4199, BGH 4355 e BGH 6371 (C. chinense)] pertencentes ao Banco de Germoplasma da UFV e um acesso [MG 302 (C. annuum)] da EPAMIG foram avaliados. No acesso BGH 6371, a aplicação de PBZ mostrou-se ineficaz em alterar a arquitetura das plantas. Nos acessos BGH 1032 e BGH 1039, a aplicação de $\mathrm{PBZ}$ na concentração de $25 \mathrm{mg} \mathrm{L}^{-1}$ resultou em plantas com melhores características ornamentais. Considerando o custo/benefício, a concentração indicada para os acessos BGH 4285, BGH 7073 e MG 302 é de 25 mg L-1 de PBZ. A aplicação de PBZ nos acessos BGH 4199 e BGH 4355, mesmo reduzindo a altura da planta, não melhorou suas características ornamentais, resultando em plantas sem padrão de copa.

Palavras-chave: Capsicum annuum, Capsicum chinense, mercado, plantas ornamentais.

\section{Received on March 1, 2019; accepted on October 10, 2019}

$\mathrm{G}$ enetic variability of genus Capsicum includes plants with different sizes. At first, any pepper variety could be used as an ornamental plant, but those with smaller, erect and more showy fruits are the most suitable for pot planting (Stommel \& Bosland, 2006; Segatto, 2007).

However, for pot cultivation, there are few commercial cultivars available, since most plants of Capsicum are relatively large and were selected for field cultivation to produce fruits for fresh consumption or for industrial processing (Finger et al., 2012).
According Poulos (1994), in the ornamental plants market, plant architecture is extremely important. The smaller ones with colorful fruits were preferred. Plant size is closely related to lineage and can be harmonized by disciplining plant growth through pruning, use of growth regulators (França et al., 2018), different pot volumes, among others. Thus, different genotypes, even those with higher growth height, can be cultivated in a pot.

Pruning is an important practice for shaping plant architecture according to the purpose (Ribeiro et al., 2015).
In pepper plants, prunings are done to increase productivity. In the cultivation of Tabasco pepper in Ceará, Brasil, two prunings are made during the crop cycle, one in the nursery and the other in the field to stimulate new branches formation, including fruits that are related to production per plant. This practice also contributes to a cup-shaped architecture of the adult plant, enabling better fruit distribution (Crisóstomo et al., 2006). However, the pepper response to pruning is quite variable and not always satisfactory for commercial production, as well as laborious. 
Ribeiro (2015), searching contrasting ornamental pepper genotypes, found that pruning was not effective on the Biquinho pepper and MG 7073 and BGH 1039 accessions, as it stimulated growth and made the crown asymmetric respectively. However, pruning conducted on two stems was effective in cultivar Ornamental Pyramid, providing denser canopy without changing plant height.

It is also possible to regulate the growth of big plants, grown in pots, through the use of growth inhibitors. For growth control, there are two widely used regulators, paclobutrazol (PBZ) $\left(\right.$ Bonzi $\left.^{\circledR}\right)$ and chlormequat chloride $\left(\right.$ Cycocel $\left.^{\circledR}\right)$. PBZ controlled stem growth of potted citrus and sunflower seedlings (Hazarika et al., 2002; Ribeiro et al., 2011). Several species of potted ornamental plants have their height effectively controlled by the application of PBZ and chlormequat chloride in the early growth phase, used commercially in Lilium longiflorum, poinsetas and Pelargonium (Currey \& Lopez, 2009).

In Pitanga pepper (C. chinense), the application of PBZ controlled plant growth (Grossi et al., 2005). These authors observed that at higher concentrations toxicity symptoms occurred, such as brittle leaves and dwarf plants. These results demonstrate that the efficiency of the regulator is dependent on the active principle concentration. According to Rademacher (2000), the growth regulators efficiency depends on the species, cultivar, application mode and plant development stage. The response and efficiency of growth retardants in pepper plants is not yet known.

The objective was to evaluate the PBZ effect on ornamental quality of pepper genotypes.

\section{MATERIAL AND METHODS}

The experiment was carried out in a greenhouse of Universidade Federal de Viçosa. The minimum and maximum daily average temperatures were 17.3 and $33.9^{\circ} \mathrm{C}$, respectively, and the relative air humidity with daily, day and night averages, 65.6 and $85.5 \%$, respectively.
The plants were kept under natural photoperiod. Seven accessions of the UFV germplasm bank [BGH 1032, BGH 1039, BGH 7073 (C. annuum), BGH 4285, BGH 4199, BGH 4355 and BGH 6371 (C. chinense)] and one access from the germplasm bank of Empresa de Pesquisa Agropecuária de Minas Gerais [MG 302 (C. annuum)] were evaluated.

Seedlings were produced in a protected environment in 120-cell polystyrene trays filled with commercial Bioplant ${ }^{\circledR}$ substrate. Reaching two to three pairs of leaves, seedlings were transplanted to $900 \mathrm{~mL}$ vessels $(11 \mathrm{~cm}$ high, $9.5 \mathrm{~cm}$ basal diameter and $13.5 \mathrm{~cm}$ higher diameter), filled with commercial Bioplant ${ }^{\circledR}$ substrate.

At transplantation, the PBZ was applied by soaking the root-substrate during five seconds in a PBZ solution at concentrations zero (control immersed in distilled water), 25,50 and $75 \mathrm{mg} \mathrm{L}^{-1}$ of the active ingredient obtained from the commercial product $\mathrm{Cultar}^{\circledR}(25 \%$ PBZ) (Seleguini et al., 2011).

During the experiment, top dressing was applied with $10 \mathrm{~g}$ NPK (10-10-10) every 20 days after transplanting, with no fertilization at planting.

Watering, from sowing to transplanting, was performed twice a day with sufficient water until its dripping on the bottom of the tray. From transplanting to seedling setting, the substrate was also irrigated twice a day. From the initial seedling establishment period to the last day of the experiment, the substrates were irrigated twice a day. Water was applied directly to the substrate without leaf wetting to prevent disease onset. Weed management was carried out manually whenever necessary.

Plants were evaluated when $50 \%$ of the population had between 10 and $30 \%$ of fully ripe fruits. We evaluated 1 ) plant height [measuring from the neck to the last fully expanded leaf using a ruler and expressed in cm (Ibraflor)]; 2) $\mathrm{LD} / \mathrm{TD}$ ratio [two measures were made in the plants canopy, one in the longitudinal diameter (LD) and other in the transverse diameter (TD) at an angle of $90^{\circ}$ to the stem position; data were obtained by the quotient between
$\mathrm{LD}$ and $\mathrm{TD}$, being considered the range of 1,0-0,7 representative of the circular canopy]; 3) Number of leaves expressed by counting the number of leaves per plant; 4) Leaf size (length/ width) (measuring the length and width of three fully expanded, randomly obtained leaves; results were expressed in $\mathrm{cm}$ ); 5) Number of ripe fruits per plant, expressed by counting fully ripe fruits per plant.

\section{Data analysis}

The experiment was set up in a completely randomized design, in which the treatments were arranged in an 8 $\times 4$ factorial scheme; eight genotypes and four concentrations of PBZ growth retardant applied to the root-substrate $\left(0,25,50\right.$ and $\left.75 \mathrm{mg} \mathrm{L}^{-1}\right)$, with three replications, each repetition consisting of one plant per pot.

The obtained data were submitted to analysis of variance by Assistat 7.7 Beta. Means were compared using Dunnett's test, adopting the $1 \%$ probability level.

\section{RESULTS AND DISCUSSION}

The BGH 1032 plants height was 40.2, 69.8 and $72.8 \%$ reduced with PBZ at 25,50 and $75 \mathrm{mg} \mathrm{L}^{-1}$, respectively. The first bifurcation height BGH 1032 plants was $60.9,78.92$ and $78.92 \%$ reduced with PBZ at 25,50 and $75 \mathrm{mg}$ $\mathrm{L}^{-1}$, respectively. However, PBZ at 50 and $75 \mathrm{mg} \mathrm{L}^{-1}$ reduced plant height too much making them dwarf. The LD/TD ratio did not differ $(x=0.87, \alpha=0,01)$ resulting in plants with good pot cover, canopy conformation and good leafing. The number of leaves and width did not differ using $25 \mathrm{mg} \mathrm{L}^{-1} \mathrm{PBZ}$. At this same concentration, the fruits number was $44.0 \%$ lower than that of control, favoring its ornamental effect. All these factors contributed to the canopy compaction without the fruits being hidden among the foliage (Table 1, Figure 1).

The BGH 1039 plant height was $72.4,79.7$ and $84.7 \%$ reduced with 25 , 50 and $75 \mathrm{mg} \mathrm{L}^{-1}$ of PBZ, respectively. However, the concentration $75 \mathrm{mg} \mathrm{L}^{-1}$ resulted in dwarf plants. First bifurcation height of BGH 1039 plants was 81.2, 87.7 and $92.2 \%$ reduced with 25,50 
Table 1. Pepper plants characteristics treated with paclobutrazol. $\mathrm{PC}=$ paclobutrazol concentration; $\mathrm{PH}=$ plant height; $\mathrm{FBH}=$ first bifurcation height; $\mathrm{LD} / \mathrm{TD}=$ longitudinal to transverse diameter ratio; $\mathrm{LL}=$ leaf length; $\mathrm{SW}=$ leaf width; $\mathrm{NL}=$ number of leaves; $\mathrm{NFr}=$ number of fruits. Viçosa, UVF, 2017.

\begin{tabular}{|c|c|c|c|c|c|c|c|c|}
\hline Access & PC $\left(\mathrm{mg} \mathrm{L}^{-1}\right)$ & PH (cm) & FBH $(\mathrm{cm})$ & LD/TD & LL (cm) & SW (cm) & $\mathbf{N L}$ & NFr \\
\hline \multirow{4}{*}{ BGH 1032} & 0 & 38.67 & 21.34 & 0.92 & 12.27 & 3.69 & 142.34 & 39.34 \\
\hline & 25 & $23.10^{*}$ & $8.34^{*}$ & $0.86^{\mathrm{ns}}$ & $9.40^{*}$ & $3.05^{\mathrm{ns}}$ & $139.67^{\mathrm{ns}}$ & $22.00^{*}$ \\
\hline & 50 & $11.67^{*}$ & $4.50^{*}$ & $0.82^{\mathrm{ns}}$ & $6.30^{*}$ & $2.42^{*}$ & $63.67^{*}$ & $15.67^{*}$ \\
\hline & 75 & $10.50^{*}$ & $4.50^{*}$ & $0.87^{\mathrm{ns}}$ & $5.50^{*}$ & $2.15^{*}$ & $42.34^{*}$ & $10.34^{*}$ \\
\hline \multirow{4}{*}{ BGH 1039} & 0 & 46.00 & 25.67 & 0.86 & 4.04 & 2.89 & 183.67 & 45.00 \\
\hline & 25 & $12.67^{*}$ & $4.83^{*}$ & $0.85^{\mathrm{ns}}$ & $5.07^{*}$ & $2.18^{\mathrm{ns}}$ & $116.67^{*}$ & $21.33^{*}$ \\
\hline & 50 & $9.33^{*}$ & $3.17^{*}$ & $0.94^{\mathrm{ns}}$ & $4.96^{*}$ & $2.08^{\text {ns }}$ & $72.67^{*}$ & $12.33^{*}$ \\
\hline & 75 & $7.00^{*}$ & $2.00^{*}$ & $0.95^{\mathrm{ns}}$ & $4.99^{*}$ & $2.13^{\text {ns }}$ & $52.67^{*}$ & $9.33^{*}$ \\
\hline \multirow{4}{*}{ BGH 7073} & 0 & 41.67 & 10.67 & 0.97 & 8.21 & 2.84 & 279.67 & 71.33 \\
\hline & 25 & $14.67^{*}$ & $3.67^{*}$ & $0.98^{\mathrm{ns}}$ & $5.40^{\mathrm{ns}}$ & $2.71^{\mathrm{ns}}$ & $175.00^{*}$ & $26.33^{*}$ \\
\hline & 50 & $13.33^{*}$ & $3.17^{*}$ & $0.92^{\mathrm{ns}}$ & $4.97^{\mathrm{ns}}$ & $2.87^{\mathrm{ns}}$ & $107.67^{*}$ & $18.33^{*}$ \\
\hline & 75 & $13.50^{*}$ & $2.50^{*}$ & $0.91^{\mathrm{ns}}$ & $4.84^{\mathrm{ns}}$ & $2.88^{\mathrm{ns}}$ & $102.67^{*}$ & $10.00^{*}$ \\
\hline \multirow{4}{*}{ MG 302} & 0 & 51.00 & 18.67 & 0.89 & 7.78 & 2.14 & 326.67 & 118.33 \\
\hline & 25 & $12.33^{*}$ & $4.67^{*}$ & $0.81^{\mathrm{ns}}$ & $4.14^{*}$ & $1.16^{*}$ & $224.00^{\mathrm{ns}}$ & $57.67^{*}$ \\
\hline & 50 & $10.50^{*}$ & $4.33^{*}$ & $0.91^{\mathrm{ns}}$ & $3.90^{*}$ & $1.12^{*}$ & $215.67^{\mathrm{ns}}$ & $36.33^{*}$ \\
\hline & 75 & $7.00^{*}$ & $2.83^{*}$ & $0.89^{\mathrm{ns}}$ & $3.01^{*}$ & $0.89^{*}$ & $169.67^{*}$ & $19.33^{*}$ \\
\hline \multirow{4}{*}{ BGH 4285} & 0 & 83.57 & 33.12 & 0.76 & 17.12 & 6.92 & 143.00 & 31.50 \\
\hline & 25 & $43.12^{*}$ & $14.50^{*}$ & $0.83^{\mathrm{ns}}$ & $15.77^{\text {ns }}$ & $5.45^{\mathrm{ns}}$ & $165.75^{\text {ns }}$ & $61.75^{*}$ \\
\hline & 50 & $45.62^{*}$ & $13.75^{*}$ & $0.75^{\mathrm{ns}}$ & $14.00^{\text {ns }}$ & $5.12^{*}$ & $124.25^{\mathrm{ns}}$ & $24.00^{*}$ \\
\hline & 75 & $51.12^{*}$ & $11.00^{*}$ & $0.84^{\mathrm{ns}}$ & $13.75^{\mathrm{ns}}$ & $4.95^{*}$ & $127.50^{\mathrm{ns}}$ & $34.00^{*}$ \\
\hline \multirow{4}{*}{ BGH 4199} & 0 & 89.50 & 38.75 & 0.64 & 14.00 & 6.37 & 163.00 & 27.50 \\
\hline & 25 & $48.00^{*}$ & $11.40^{*}$ & $0.82^{\mathrm{ns}}$ & $11.00^{\mathrm{ns}}$ & $5.00^{\mathrm{ns}}$ & $132.00^{\mathrm{ns}}$ & $40.00^{*}$ \\
\hline & 50 & $53.00^{*}$ & $12.00^{*}$ & $0.86^{\mathrm{ns}}$ & $12.50^{\text {ns }}$ & $5.50^{\text {ns }}$ & $121.50^{\mathrm{ns}}$ & $53.50^{*}$ \\
\hline & 75 & $72.75^{*}$ & $16.25^{*}$ & $0.59^{\mathrm{ns}}$ & $12.62^{\mathrm{ns}}$ & $5.05^{\text {ns }}$ & $111.75^{\mathrm{ns}}$ & $58.00^{*}$ \\
\hline \multirow{4}{*}{ BGH 4355} & 0 & 108.50 & 36.00 & 0.76 & 14.87 & 7.82 & 166.25 & 15.50 \\
\hline & 25 & $81.25^{*}$ & $20.00^{*}$ & $0.49^{\mathrm{ns}}$ & $13.02^{\mathrm{ns}}$ & $7.00^{\mathrm{ns}}$ & $148.00^{\mathrm{ns}}$ & $4.75^{*}$ \\
\hline & 50 & $96.00^{\text {ns }}$ & $15.50^{*}$ & $0.69^{\text {ns }}$ & $14.30^{\text {ns }}$ & $7.24^{\mathrm{ns}}$ & $140.25^{\mathrm{ns}}$ & $6.00^{*}$ \\
\hline & 75 & $77.00^{*}$ & $13.75^{*}$ & $0.65^{\text {ns }}$ & $11.67^{\mathrm{ns}}$ & $4.87^{*}$ & $136.00^{\mathrm{ns}}$ & $13.25^{\text {ns }}$ \\
\hline \multirow{4}{*}{ BGH 6371} & 0 & 82.00 & 39.50 & 0.77 & 17.82 & 8.12 & 125.50 & 30.25 \\
\hline & 25 & $61.25^{\mathrm{ns}}$ & $28.25^{*}$ & $0.61^{\mathrm{ns}}$ & $16.40^{\text {ns }}$ & $8.50^{\mathrm{ns}}$ & $75.50^{*}$ & $28.25^{\mathrm{ns}}$ \\
\hline & 50 & $66.75^{\text {ns }}$ & $26.00^{*}$ & $0.62^{\mathrm{ns}}$ & $16.60^{\text {ns }}$ & $7.50^{\mathrm{ns}}$ & $77.75^{*}$ & $30.75^{\text {ns }}$ \\
\hline & 75 & $59.25^{\mathrm{ns}}$ & $18.02^{*}$ & $0.63^{\mathrm{ns}}$ & $18.00^{\text {ns }}$ & $7.62^{\mathrm{ns}}$ & $52.75^{*}$ & $18.75^{\text {ns }}$ \\
\hline
\end{tabular}

Means followed by $(*)$ differ from control by Dunnett's test at $1 \%$ probability. Means followed by (ns) do not differ from control by the Dunnett Test at $1 \%$ probability.

and $75 \mathrm{mg} \mathrm{L}^{-1} \mathrm{PBZ}$, respectively. The $\mathrm{LD} / \mathrm{TD}$ ratio was not changed $(\mathrm{x}=0.90$, $\alpha=0.01$ ), keeping the canopy circular. Leaf and fruit numbers were reduced at all PBZ concentrations. However, the leaf and fruit numbers reduction were proportional to the plant height reduction, maintaining the ornamental balance (Table 1, Figure 1).

BGH 7073 total height and first bifurcation decreased with PBZ application. The LD/TD ratio and leaf characteristics were not altered with the PBZ application. However, the leaves number was reduced by $37.4,61.5$ and $63.28 \%$ for 25,50 and $75 \mathrm{mg} \mathrm{L}^{-1}$ PBZ, respectively. The fruits number was also reduced with PBZ. However, the smallest reduction $(63.1 \%)$ was observed with the application of $25 \mathrm{mg}$ $\mathrm{L}^{-1}$ PBZ (Table 1, Figure 1).

Plant height of MG 302 was 75.8 , 79.4 and $86.2 \%$ reduced with 25,50 and $75 \mathrm{mg} \mathrm{L}^{-1} \mathrm{PBZ}$, respectively. The first bifurcation height was reduced by $74.9,76.8$ and $84.8 \%$ with 25,50 and 75 mg L ${ }^{-1}$ PBZ, respectively. The LD/TD ratio did not differ $(x=0.88, \alpha=0.01)$, resulting in plants with good crown conformation. The leaves number was reduced (48.1\%) with $75 \mathrm{mg} \mathrm{L}^{-1} \mathrm{PBZ}$. The fruits number was also reduced but remained proportional to the plant size without changing its ornamental aspect (Table 1, Figure 1).

BGH 4285 total and first height were 


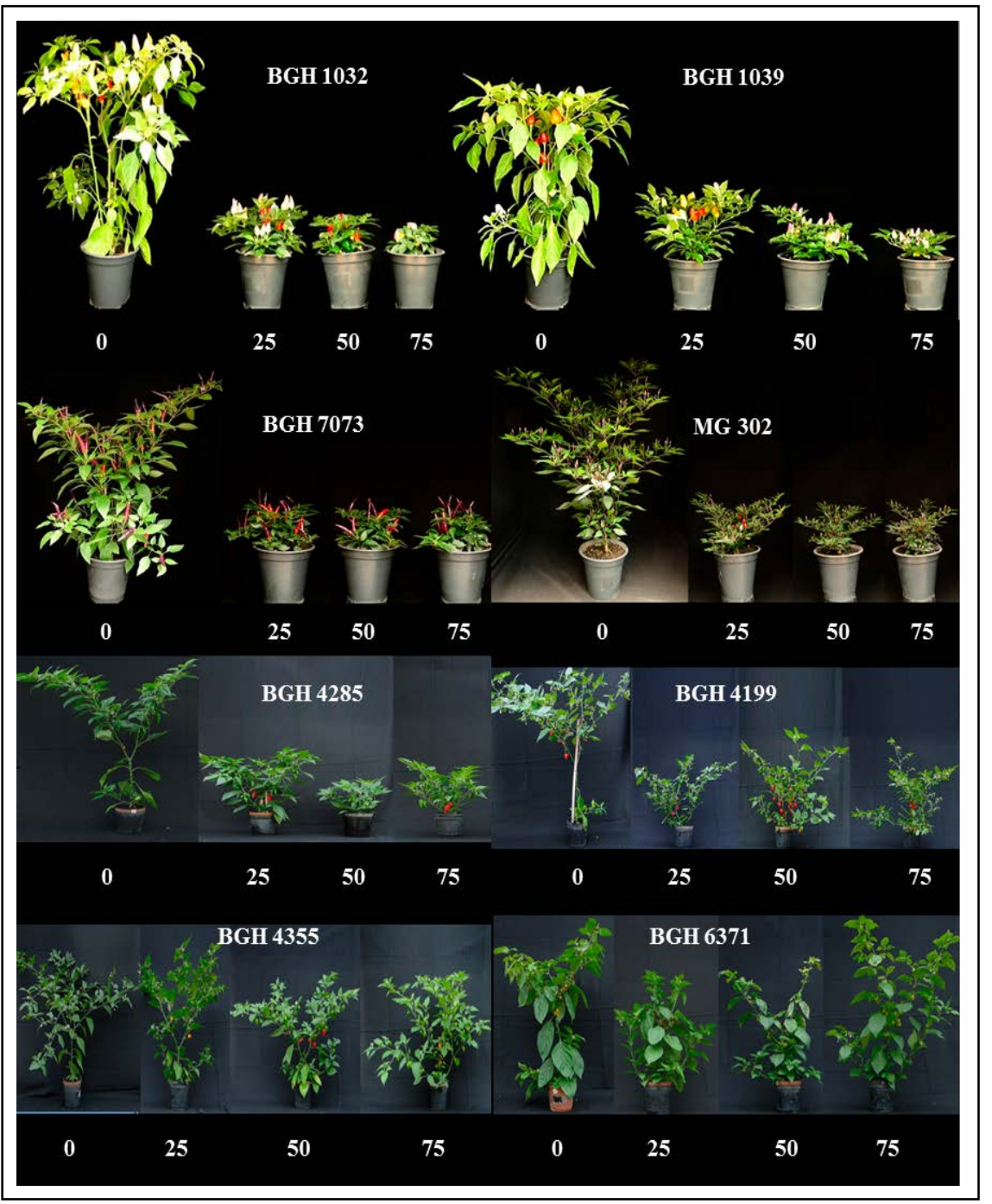

Figure 1. Pepper plants visual appearance treated with paclobutrazol at concentrations of 0 , 25, 50, $75 \mathrm{mg} \mathrm{L}^{-1}$ and control. Viçosa, UFV, 2017.

48.6 and $56.2 \%$ reduced, respectively, with $25 \mathrm{mg} \mathrm{L}^{-1} \mathrm{PBZ}$. This reduction fitted the plants to Veiling Holambra's height standards for pots number 19 and 20 , which is 16 to $44 \mathrm{~cm}$ high. The $\mathrm{LD} /$ TD ratio, at $25 \mathrm{mg} \mathrm{L}^{-1} \mathrm{PBZ}$, was close to $1(0.83)$, resulting in plants with good pot cover and canopy conformation. The leaves number and length did not differ with PBZ, but width was reduced. All these factors contributed to the canopy compaction without fruits being hidden among the foliage. The fruits number was $49.0 \%$ higher than from control, favoring its ornamental effect. PBZ application at 50 and $75 \mathrm{mg} \mathrm{L}^{-1}$ resulted in BGH 4285 plants with good crown conformation. However, the fruits number was higher with the application of $25 \mathrm{mg} \mathrm{L}^{-1} \mathrm{PBZ}$ (Table 1, Figure 1).
BGH 4199 total and first bifurcation height were reduced with $\mathrm{PBZ}$ application. Plants that received 75 $\mathrm{mg} \mathrm{L}^{-1} \mathrm{PBZ}$ were prostrated. The LD/ TD ratio did not differ. Fruits number increased $52.6 \%$ with PBZ application at a concentration of $75 \mathrm{mg} \mathrm{L}^{-1}$.

The total and first bifurcation height of BGH 4355 plants was reduced with PBZ at 25 and $75 \mathrm{mg} \mathrm{L}^{-1}$, however, this reduction was not sufficient to fit them into Veiling Holambra commercial standards. The LD/TD ratio, number and length of leaves and fruits number did not differ (Table 1, Figure 1).

The application of $75 \mathrm{mg} \mathrm{L}^{-1} \mathrm{PBZ}$ on BGH 6371 access reduced the height of the first bifurcation $(82.0 \%)$, but there was no change in the total plant height. The leaves number was reduced (44.3\%) with PBZ. The other characteristics did not differ (Table 1, Figure 1).

The plant and first bifurcation height reduction observed with PBZ application is basically due to synthesis of gibberellins inhibition, which are responsible for the expansion and elongation of the meristem cells that will form the internode (Barret et al., 1994; Rademacher, 1991; Basra, 2000; Taiz \& Zeiger, 2004).

The PBZ application on Pitanga pepper (C. chinense) controlled plants growth but in higher concentrations there were toxicity symptoms, such as brittle leaves and dwarf plants (Grossi et al., 2005). These results demonstrate that the PBZ efficiency is dependent on the concentration of the active principle, species, cultivar, plant development stage and application mode (Rademacher, 2000). França (2015) concluded that the PBZ concentration of $20 \mathrm{mg} \mathrm{L}^{-1}$ in Bode Amarela pepper plants and in the $2345 \mathrm{~PB}$ access provided adequate height for ornamentation, without altering fruit characteristics and phytotoxicity. The same concentration (20 $\mathrm{mg} \mathrm{L}^{-1}$ ) applied to cultivar Iracema and access 2334PB caused toxicity symptoms presenting snappy and brittle leaves.

Gent (1995), Francescangeli et al. (2007), Wanderley et al. (2014) and Carvalho (2010) also observed varied responses in reducing plant height of different genotypes in relation to the PBZ doses application in azalea, lily, sunflower and mini roses, respectively. According to Sachs \& Hackett (1976), Barbosa (2003) and Brum et al. (2007), the ornamental plants height grown in pots should be 1.5 to 2 times the height of the same, that is, between 15 and 20 $\mathrm{cm}$ for pots of $10 \mathrm{~cm}$, as in the present work. This height was obtained with the $25 \mathrm{mg} \mathrm{L}^{-1}$ dose in the BGH 1032, BGH 1039, BGH 4285, BGH 6371 and BGH 7073 accesses.

The fruits number reduction per plant observed in BGH 1023, BGH 1039, BGH 7073, MG 302 and BGH 4355 , is explained by the reduction of the canopy itself and, consequently, of productive branches (reduction of vegetative growth) associated with the change in the pattern, distribution 
of photoassimilates, diverting them to reproductive development (Khalil \& Aly, 2013). PBZ, therefore, inhibiting gibberellic acid biosynthesis (Rademacher, 2000) may cause flowering delay and, consequently, fewer fruits on the plant. Although ornamental pepper plants, which have fruits as their main decorative elements, suffered a reduction in the fruits number per plant at the lowest concentration, their ornamental quality was not affected, since the reduction was proportional to plant height.

The LD/TD ratio was not significant for any PBZ concentration in the evaluated genotypes. However, plant diameter was reduced with $\mathrm{PBZ}$ application, in agreement with Grossi et al. (2005), Tinoco et al. (2011) and Bosch et al. (2016). This plant diameter reduction is directly related to the internode elongation reduction due to gibberellin biosynthesis inhibition. The reduction in plant diameter makes it more compact, thus preventing the substrate from becoming apparent from above. This feature is desirable and already serves as a quality standard for potted ornamental plants such as chrysanthemum, may flower, gerbera and kalanchoe (Ibraflor, 2019).

In BGH 4285, BGH 7073, MG 302, BGH 1032 and BGH 1039, the PBZ application in the concentration of 25 $\mathrm{mg} \mathrm{L}^{-1}$ is the most indicated; resulting in plants with better ornamental characteristics. The PBZ application did not improve the ornamental characteristics of the BGH 4199 and $\mathrm{BGH}$ 4355. In BGH 6371, the PBZ application showed no effect.

\section{REFERENCES}

BARBOSA, JG. 2003. Chrysanthemums: Seedling production, cultivating for flower cuts, potted cultivation, hydroponic cultivation. Aprenda Fácil, 232p.

BARRET, JE; BARTUSKA, CA; NELL, TA. 1994. Comparison of paclobutrazol drench and spike applications for height control of potted floriculture crops. HortScience 29: 893-895.
BASRA, AS. 2000. Plant growth regulators in agriculture and horticulture: their role and commercial uses. 1. ed. New York: Food Products Press. p. 262.

BOSCH, E; CUQUEL, FL; TOGNON, GB. 2016. Physalis size reduction for potted ornamental plant use. Ciência e Agrotecnologia 40: 555-564.

BRUM, B; SANTOS, VJ; RODRIGUES, MA; BELLÉ, RA. 2007. Crescimento, duração do ciclo e produção de inflorescências de crisântemo multiflora sob diferentes números de despontes e tamanhos de vasos. Ciência Rural 37: 682-689.

CARVALHO, MP. 2010. Retardantes de crescimento na produção, qualidade e plasticidade anatômica de roseiras de vaso. Viçosa: UFV 30p. (M.Sc. Thesis).

CRISÓSTOMO, JR; FURTADO, RF; ABREU, FR; CRISÓSTOMO, LA; MIRANDA, FR; BLEICHER, E; RODRIGUES, SMM; WEBER, OB; REIS, A; ROCHA FILHO, RR; GONDIM, RS; GIRÃO, EG. 2006. Cultivo de pimenta Tabasco no Ceará. Fortaleza: Embrapa Agroindústria Tropical. 34p.

CURREY, CJ; LOPEZ, RG. 2009. Applying plant growth retardants for height control. In: Commercial greenhouse and nursery production. Purdue Extension, 10p.

FINGER, FL; RÊGO, ER; SEGATTO, FB; FERREIRA, NF; RÊGO, MM. 2012. Produção e potencial de mercado para pimenta ornamental. Informe Agropecuário 33: 14-20.

FRANÇA, CFM.; RIBEIRO, WS; SANTOS, MNS; PETRUCCI, KPOS; RÊGO, ER; FINGER, FL. 2018. Growth and quality of potted ornamental peppers treated with paclobutrazol. Pesquisa Agropecuária Brasileira 53: 316-322.

FRANCESCANGELI, N; MARINANGELI, P; CURVETTO, N. 2007. Paclobutrazol for height control of two Lilium L.A. hybrids grown in pots. Journal of Agriculture Research 5: 425-430.

GENT, MPN. 1995. Paclobutrazol or uniconazol applied early in the previous season promotes flowering of field-grown Rhododendron and Kalmia. Journal of Plant Growth Regulation 14: 205-210.

GROSSI, JAS; MORAES, PJ; TINOCO, SA; BARBOSA, JG; FINGER, FL; CECON, PR. 2005. Effects of paclobutrazol on growth and fruiting characteristics of 'Pitanga' ornamental pepper. Acta Horticulturae 683: 333-336.

HAZARIKA, BN; PARTHASARATHY, VA; NAGARAJU, V. 2002. Action of paclobutrazol in acclimatizing micropropagated citrus plantlets. Indian Journal for Agricultural Research 36: 57-60.

I N S T I T U T O B R A S I L E I R O D E FLORICULTURA (Ibraflor). Números do setor: mercado interno. Available at $<\mathrm{http} / / /$ www.IBRAFLOR.com/ns_mer_interno.php>. Accessed August 7, 2019.
KHALIL, HA; ALY, HS. 2013. Cracking and fruit quality of pomegranate (Punica granatum L.) as affected by pre-harvest sprays of some growth regulators and mineral nutrients. Journal of Horticultural Science \& Biotechnology 5: 71-76.

POULOS, JM. 1994. Pepper breeding (Capsicum spp.): achievements, challenges and possibilities. Plant Breeding Abstracts 64: 144-155.

RADEMACHER, W. 1991. Inhibitors of gibberellins biosynthesis: Applications in agriculture and horticulture. In: TAKAHASHI, NB; PHINNEY; MacMILLAN, J (eds). Gibberellins. New York: Springer-Verlag. p.296-310.

RADEMACHER, W. 2000. Growth retardants: effects on gibberellin biosynthesis and other metabolic pathways. Annual Review of Plant Physiology and Molecular Biology 51: 501531.

RIBEIRO, DM; MÜLLER, C; BEDIN, J; ROCHA, GB; BARROS, RS. 2011. Effects of autoclaving on the physiological action of paclobutrazol. Agricultural Sciences 2: 191-197.

RIBEIRO, WS; COSTA, LC; PINTO, CMF; SILVA, FC; FINGER, FL. 2015. Effect of pruning on ornamental value of potted pepper (Capsicum spp.). Acta Horticulturae 1060: 249-254.

SACHS, RM; HACKETT, WP. 1976. Chemical control of flowering. Acta Horticulturae 68: 29-49.

SEGATTO, FB. 2007. Evaluation quality "postproduction" of ornamental pepper (Capsicum annuum L.) cultivated in pots. Viçosa: UFV. 100p (P.Hd. Thesis).

SELEGUINI, A; FARIA JÚNIOR, MJA; SENO, S; SANTOS, JI; SILVA, KS; LEMOS, OL. 2011. Vida útil e qualidade de frutos de tomateiros tratados com paclobutrazol. Revista Ceres 58: 470-475.

STOMMEL, JR; BOSLAND, PW. 2006. Ornamental pepper, Capsicum annuum. In: Anderson, N (ed). Flower Breeding and Genetics: Issues, Challenges and opportunities for the 21 st Century. Dordrecht: Springer. p.561-599.

TAIZ, L; ZEIGER, E. 2004. Fisiologia vegetal. Porto Alegre: Artmed. p.449-484.

TINOCO, SA; GROSSI, JAS; AZEVEDO, AA; BARBOSA, JG; SANTOS, NT. 2011. Produção e qualidade de plantas de gerânio zonal (Pelargonium $x$ hortorum L.H. Bailey) em resposta à aplicação de clormequat, daminozide e paclobutrazol via foliar. Revista Brasileira de Horticultura Ornamental 17: 149-158.

WANDERLEY, CS; FARIA, RT; REZENDE, R. 2014. Crescimento de girassol como flor em vaso em função de doses de paclobutrazol. Revista Ceres 61: 35-41. 